\title{
Modal Sosial Masyarakat di Kawasan Penyangga Taman Nasional Gunung Ciremai untuk Mendukung Skema Pengelolaan Berbasis Kemitraan
}

\author{
Rahmat Hidayat ${ }^{1}$ \\ Program Doktor IImu Kehutanan, Fakultas Kehutanan, Universitas Gadjah Mada \\ Yogyakarta, Indonesia
}

\author{
Djoko Marsono \\ Departemen Konservasi Sumberdaya Hutan, Fakultas Kehutanan \\ Universitas Gadjah Mada, Yogyakarta, Indonesia
}

\section{Sahid Susanto}

Departemen Teknik Pertanian dan Biosistem, Fakultas Teknologi Pertanian

Universitas Gadjah Mada, Yogyakarta, Indonesia

\section{Ronggo Sadono}

Departemen Manajemen Hutan, Fakultas Kehutanan

Universitas Gadjah Mada, Yogyakarta, Indonesia

Artikel Masuk : 7 Oktober 2019

Artikel Diterima : 3 Agustus 2020

Tersedia Online : 31 Agustus 2020

\begin{abstract}
Abstrak: Pemahaman modal sosial masyarakat memiliki peranan penting dalam mendukung pengelolaan kawasan konservasi berbasis kemitraan. Penelitian ini bertujuan untuk menilai karakteristik unsur-unsur modal sosial serta mengukur hubungan pengaruh unsur-unsur modal sosial terhadap modal sosial di masing-masing desa di sekitar kawasan penyangga TNGC dengan mengambil lokasi penelitian di kawasan penyangga Taman Nasional Gunung Ciremai (TNGC). Lokasi penelitian difokuskan pada wilayah hulu Daerah Aliran Sungai (DAS) Cisanggarung. Pengumpulan data dilakukan melalui tiga tahapan yaitu studi pustaka, survei lapangan, dan wawancara. Metode analisis dilakukan dengan menggunakan uji deskriptif dan confirmatory factor analysis. Hasil penelitian menunjukkan modal sosial masyarakat di sekitar kawasan penyangga TNGC, walaupun dalam satuan ekosistem DAS yang sama memiliki karakteristik yang bervariasi. Fakta ini dibuktikan dengan adanya perbedaan kategori modal sosial dan unsur modal sosial yang paling berpengaruh dalam pembentukan modal sosial di area pedesaan yang menjadi kawasan penyangga. Dalam rangka mendukung skema pengelolaan TNGC berbasis kemitraan maka sub unsur modal sosial yang berada pada level sangat lemah dan lemah, serta unsur modal sosial yang paling berpengaruh dalam pembentukan modal sosial tiap desa, harus menjadi pertimbangan utama dalam peningkatan modal sosial dan penyusunan program kemitraan konservasi yang akan dilakukan di tiap desa.
\end{abstract}

\footnotetext{
${ }^{1}$ Korespondensi Penulis: Program Doktor Ilmu Kehutanan, Fakultas Kehutanan, Universitas Gadjah Mada Yogyakarta, Indonesia

Email: galunggungmerah@yahoo.com
} 


\title{
131 Modal Sosial Masyarakat di Kawasan Penyangga Taman Nasional Gunung Ciremai . . .
}

Kata Kunci: confirmatory factor analysis, kawasan penyangga; kemitraan; modal sosial; taman nasional

\begin{abstract}
Understanding about social capacital of community has an essential role in supporting the collaborative management of conservation area. This study aims to assess the characteristics of elements of social capital and measure the relationship of the effects of elements of social capital on social capital owned by communities around the buffer zone of Taman Nasional Gunung Ciremai (TNGC). Study site was located in the upstream area of Cisanggarung watershed. Data collection was undertaken through three stages, i.e. literature study, field observation, and inteview. The analysis was conducted using confirmatory factor analysis and descriptive test. The results demonstrated that the social capacital of communities around the buffer zone of TNGC, even though in the same watershed ecosystem unit they had varied characteristics. This fact is proven by the differences in social capital categories and the most influential elements of social capital in the formation of social capital in rural areas that are buffer zones. In order to support the collaborative management in TNGC, the sub-elements of social capital which is at a very weak and weak level, as well as the most influential social capital element in the formation of social capital in each village, should be the main consideration in increasing social capital and preparing conservation collaborative programs that are will be done in each village.
\end{abstract}

Keywords: buffer zone; collaborative; confirmatory factor analysis; national park; social capital

\section{Pendahuluan}

Kehadiran masyarakat di sekitar kawasan penyangga area konservasi menjadi salah satu aspek yang harus dipertimbangkan dalam merumuskan skenario pengelolaan kawasan konservasi secara efektif, efisien, dan beradab. Hal ini dilatarbelakangi oleh fakta yang menunjukkan bahwa terdapat 6.381 wilayah pedesaan yang berada di sekitar area konservasi (Wiratno, 2018). Keseluruhan desa tersebut memiliki persamaan kondisi dengan mayoritas masyarakatnya bergantung pada sumber daya yang terdapat di dalam kawasan konservasi (Hamdan, Achmad, \& Mahbub, 2017; Massiri, Nugroho, Kartodihardjo, \& Soekmadi, 2016; Ristianasari, Muljono, \& Gani, 2016). Fenomena ini merupakan salah satu tantangan yang harus dihadapi untuk menjaga kelestarian kawasan konservasi dan kelimpahan sumber daya alam pada ekosistemnya.

Eksistensi masyarakat di sekitar kawasan konservasi memiliki ketergantungan serta keterikatan yang kuat sehingga menyebabkan adanya interaksi baik secara positif maupun negatif terhadap potensi dan sumber daya alam yang berada di dalam kawasan konservasi (Lestari, Agussabti, \& Alibasyah, 2014; Narsuka, Retnowati, \& Setiawan, 2009). Dalam konteks ini, aktivitas yang dilakukan telah berlangsung secara turun temurun dan menjadi bagian dari dinamika ekosistem yang berlangsung di dalam kawasan konservasi. Pengelolaan kawasan konservasi secara terpadu semestinya dilakukan dengan melibatkan partisipasi masyarakat untuk mewujudkan tujuan pengelolaan (Sadono, 2013; Yanto, 2012). Skenario ini dapat diterapkan dengan mempertimbangkan berbagai aspek yaitu pengakuan eksistensi masyarakat, kompleksitas dinamika sistem sosial-ekologis, dan kolaborasi manajemen (Sabir, Avenzora, \& Winarno, 2018). Integrasi ketiga aspek tersebut dapat dirangkum dalam terminologi pengelolaan kawasan konservasi berbasis kemitraan (Direktorat Konservasi Kawasan, 2018; Negara, 2011; Nordiansyah, Ismail, \& Bakrie, 2016).

Taman Nasional Gunung Ciremai (TNGC) merupakan salah satu kawasan konservasi yang terletak di Provinsi Jawa Barat dengan luas mencapai 14.841,3 ha. Kawasan TNGC memiliki fungsi penting salah satunya sebagai catchment area yang menopang dan menjaga kestabilan tujuh ekosistem Daerah Aliran Sungai (DAS) besar yang berhulu di 
kawasan TNGC, yaitu DAS Cisanggarung, Kalibangkaderes, Kalisuba, Cipager, Ciwaringin, Cilutung, Cimanuk. Kawasan TNGC saat ini dikelilingi oleh lima puluh empat wilayah pedesaan (Balai Taman Nasional Gunung Ciremai, 2015). Informasi ini mengindikasikan bahwa skenario pengelolaan kawasan konservasi berbasis kemitraan sangat dibutuhkan untuk menjaga kelestarian ekosistem TNGC.

Implementasi pengelolaan kawasan konservasi berbasis kemitraan salah satunya perlu mempertimbangkan aspek sosial dan potensi kawasan (Direktorat Konservasi Kawasan, 2018). Salah satu data aspek sosial yang penting yaitu terkait modal sosial. Modal sosial merupakan aset penting yang berkaitan dengan pola kerjasama untuk memberikan manfaat kepada masyarakat agar dapat meningkatkan kualitas hidup (Hakim \& Wibisono, 2017; Nugrahani, Suharni, \& Saptatiningsih, 2019). Dalam pengelolaan sumber daya milik bersama salah satunya kawasan konservasi, modal sosial berfungsi untuk membentuk tindakan kolektif, dan memobilisasi tindakan-tindakan yang kompetitif serta membangun persepsi dan dukungan positif dalam pemanfaatan dan pengelolaan sumber daya alam, yang keberadaannya bergantung pada karakteristik sosial dan budaya masyarakat (BarnesMauthe, Gray, Arita, Lynham, \& Leung, 2014; Bisung, Elliott, Schuster-Wallace, Karanja, \& Bernard, 2014; Jones, Clark, Panteli, Proikaki, \& Dimitrakopoulos, 2012; Ostrom, 1990; Roslinda, 2018). Modal sosial dan peran lembaga lokal merupakan salah satu faktor yang memengaruhi pengelolaan sumber daya alam, termasuk salah satunya pengelolaan taman nasional di samping modal fisik dan ekonomi (Barnes-Mauthe et al., 2014, 2015; Szulecka \& Secco, 2014), modal sosial juga dapat dinilai sebagai sebuah jasa lingkungan (BarnesMauthe et al., 2015).

Kemitraan konservasi di kawasan TNGC telah dilakukan salah satunya melalui program pemberdayaan masyarakat, bentuknya melalui pemberian bantuan usaha ternak, maupun kemitraan dalam pengelolaan usaha jasa wisata alam dan air. Namun demikian, di lapangan masih ditemukan kasus konflik pemanfaatan air, wisata, pencurian kayu, dan kebakaran hutan, yang menunjukkan bahwa masih belum optimalnya pelaksanaan kemitraan konservasi tersebut. Oleh karena itu, untuk efektifitas implementasi kemitraan konservasi dan pengelolaan kawasan kawasan TNGC secara umum maka identifikasi modal sosial masyarakat penting dilakukan, yang selama ini kegiatan tersebut belum pernah dilakukan oleh pihak Balai TNGC.

Beberapa penelitian terkait modal sosial dan kemitraan di kawasan konservasi di Indonesia sudah dilakukan. Oktadiyani, Muntasib, \& Sunkar (2013) mengkaji modal sosial untuk mendukung pengembangan ekowisata di zona penyangga Taman Nasional Kutai (TNK), dengan kajian dilakukan di dua dusun yang berbatasan dengan kawasan TNK. Hasil penelitian menunjukkan bahwa tingginya nilai modal sosial di Dusun Kabo Jaya akan memberikan pengaruh untuk mudahnya pengembangan ekowisata di dusun tersebut, dibandingkan dengan dusun G III yang berada pada nilai sedang. Effendi, Barkey, \& Jamil (2014) mengkaji implementasi program pemberdayaan masyarakat di dua model desa konservasi di Taman Nasional Taka Bonerate, yang hasilnya secara umum dinilai cukup baik dan berhasil. Permasalahan yang ditemukan pada setiap tahapan secara umum terkait belum aktifnya stakeholder dan masyarakat dalam mengikuti pertemuan dan belum dibangunnya kelompok atas inisiatif masyarakat sendiri. Roslinda (2018) mengidentifikasi dan menilai modal sosial masyarakat serta peran modal sosial masyarakat dengan model kelembagaan pengelolaan Taman Nasional Danau Sentarum (TNDS) dengan kajian dilakukan di seluruh kawasan TNDS yang terdiri dari tiga seksi wilayah pengelolaan. Hasil penelitian menunjukkan bahwa modal sosial masyarakat di kawasan TNDS masih tinggi/kuat. Selanjutnya Sulistyorini, Poedjirahajoe, Rahayu, \& Faida (2018) melakukan kajian modal sosial dalam mendukung pemanfaatan mangrove untuk silvofishery, di wilayah yang berstatus areal penggunaa lain yang berbatasan dengan kawasan Taman Nasional Kutai. Hasil penelitian menunjukkan bahwa jaringan sosial dan normal sosial 


\section{Modal Sosial Masyarakat di Kawasan Penyangga Taman Nasional Gunung Ciremai ...}

merupakan elemen yang tidak berpengaruh terhadap program silvofishery. Penelitianpenelitian tersebut di atas, umumnya dilakukan dengan batasan wilayah penelitiannya pada satuan wilayah desa, seluruh wilayah pengelolaan Taman Nasional dan areal hutan mangrove.

Penelitian ini berfokus pada karakteristik modal sosial pada satuan wilayah desa dan pada satuan ekosistem, yaitu di masing-masing desa penyangga TNGC yang berada dalam satuan ekosistem yang sama dalam hal ini DAS Cisanggarung. Hal ini didasarkan karena pertama TNGC merupakan kawasan penting untuk tangkapan air bagi lima DAS besar, sehingga karakteristik masing-masing ekosistem DAS perlu diketahui. Menurut Asdak (2002), DAS sebagai sebuah satuan ekosistem memiliki karakteristik biofisik dan sosial yang khas yang berbeda antara satu DAS dengan lainnya. Selanjutnya yang kedua karena program kemitraan konservasi dilakukan pada tingkat tapak pada satuan desa (Direktorat Konservasi Kawasan, 2018), maka identifikasi modal sosial masing-masing desa perlu diketahui. Oleh karena itu, penelitian ini bertujuan untuk menilai karakteristik unsur-unsur modal sosial serta mengukur hubungan pengaruh unsur-unsur modal sosial terhadap modal sosial di masing-masing desa di sekitar kawasan penyangga TNGC dengan mengambil lokasi penelitian di Hulu DAS Cisanggarung.

\section{Metode Penelitian}

\section{Lokasi dan Waktu Penelitian}

Penelitian ini dilaksanakan di wilayah hulu DAS Cisanggarung, yang meliputi enam desa yaitu Desa Gunung Sirah, Karangsari, dan Sagarahiang di Kecamatan Darma, Desa Puncak dan Cisantana di Kecamatan Cigugur, dan Desa Sukamukti di Kecamatan Jalaksana. yang secara administratif, terletak di Kabupaten Kuningan. Enam desa tersebut merupakan total desa yang mempunyai interaksi dan ketergantungan langsung dengan wilayah hulu DAS Cisanggarung. Waktu penelitian dilaksanakan selama 7 bulan mulai dari Desember 2017- Juni 2018. Lokasi Penelitian ditampilkan pada Gambar 1.

\section{Pengumpulan Data}

Pengumpulan data dilakukan melalui tiga tahap yaitu studi literatur, survei lapangan, dan wawancara. Studi literatur dilakukan untuk membangun instrumen kuesioner sedangkan survei lapangan dilakukan untuk mengamati secara langsung kondisi sosial ekonomi budaya masyarakat dan penerapan unsur modal sosial oleh masyarakat di setiap desa kajian. Selanjutnya, pelaksanaan wawancara adalah untuk mengetahui persepsi dan penilaian masyarakat terhadap unsur modal sosial, yang dilakukan dengan menggunakan panduan kuesioner. Responden adalah kepala keluarga yang tinggal di desa kajian. Total responden ditentukan dengan rumus Slovin pada tingkat galat 7\% (Asari, Toloh, \& Sangari, 2014). Sebaran dan jumlah responden masing-masing desa penelitian ditampilkan pada Tabel 1.

Tabel 1. Sebaran dan Jumlah Responden Masing-Masing Desa Penelitian

\begin{tabular}{|c|c|c|}
\hline No & Desa Penelitian & Jumlah Sampel \\
\hline 1 & Gunung Sirah & 30 \\
\hline 2 & Karang Sari & 30 \\
\hline 3 & Sagarahiang & 47 \\
\hline 4 & Puncak & 40 \\
\hline 5 & Cisantana & 61 \\
\hline \multirow[t]{2}{*}{6} & Sikamukti & 31 \\
\hline & Total & 239 \\
\hline
\end{tabular}


Data yang dikumpulkan adalah unsur-unsur modal sosial yang terdiri dari kepercayaan, norma sosial, jaringan, tindakan proaktif, dan kepedulian terhadap sesama dan lingkungan. Indikator penilaian unsur modal sosial mengacu pada Measuring Sosial Capital. An Integrated Quitionnaire (Grootaert et al., 2004) yang dimodifikasi sesuai dengan karakteristik lokasi penelitian. Unsur dan subunsur atau indikator modal sosial yang dinilai di lapangan ditampilkan pada Tabel 2. Dalam pengukuran tingkatan masing-masing unsur modal sosial, semua pertanyaan kuisioner disusun dalam skala likert, yaitu sangat tidak setuju (1), tidak setuju (2), normal (3), setuju (4), dan sangat setuju (5). Penggunaan skala likert dalam penelitian ini karena alternatif setiap jawaban responden dapat ditransformasikan menjadi data kuantitatif, dengan cara pemberian skor. Skor yang diperoleh tersebut dapat dipertimbangkan sebagai data interval, yang dapat ditindaklanjuti dengan analisis statistik parametrik lainnya (Budiaji, 2013; Marliani, 2010; Subroto, Farisa, \& Haviana, 2016).

\section{Tabel 2. Unsur dan Sub Unsur Modal Sosial yang Dinilai di Lapangan}

\begin{tabular}{|c|c|}
\hline Unsur & Subunsur \\
\hline Kepercayaan & $\begin{array}{l}\text { - } \text { kepercayaan terhadap sesama warga } \\
\text { - } \text { kepercayaan terhadap pemimpin/aparat desa } \\
\text { - } \text { kepercayaan terhadap tokoh masyarakat/adat/agama } \\
\text { - } \text { kepercayaan terhadap balai TNGC } \\
\text { - } \text { kepercayaan terhadap kelompok/lembaga pemanfaatan air } \\
\text { - kepercayaan terhadap kelompok wisata alam } \\
\text { - kepercayaan terhadap kelompok tani } \\
\text { - kepercayaan terhadap lembaga swadaya masyarakat } \\
\text { - kepercayaan terhadap warga desa lain } \\
\text { - } \text { kepercayaan terhadap perusahaan atau industri yang memanfaatkan jasa } \\
\end{array}$ \\
\hline Norma & $\begin{array}{l}\text { - terdapatnya norma adat tentang pengelolaan dan pemanfaatan sumber daya alam } \\
\text { - } \text { pemahaman dan kepatuhan terhadap norma adat, } \\
\text { - } \text { pemahaman dan kepatuhan terhadap norma kesusilaan } \\
\text { - pemahaman dan kepatuhan terhadap norma kesopanan } \\
\text { - pemahaman dan kepatuhan terhadap norma agama } \\
\text { - pepatuhan terhadap peraturan pemerintah }\end{array}$ \\
\hline Jaringan sosial & $\begin{array}{l}\text { - kepadatan jaringan, } \\
\text { - keragaman jaringan, } \\
\text { - } \text { motivasi atau kerelaan membangun jaringan, } \\
\text { - } \text { partisipasi dan keaktifan dalam memilihara dan mengembangkan jaringan, } \\
\text { - tingkat kerjasama dalam komunitas } \\
\text { - dan tingkat kerjasama di luar komunitas }\end{array}$ \\
\hline Tindakan proaktif & $\begin{array}{l}\text { - keaktifan dalam melakukan kegiatan-kegiatan inovatif untuk lingkungan dan } \\
\text { masyarakat } \\
\text { - } \text { inisiatif secara pribadi untuk mengembangkan, memelihara dan memperbaiki } \\
\text { fasilitas umum } \\
\text { - keaktifan menghadiri dan memberikan pendapat dalam pertemuan } \\
\text { - keaktifan dalam kegiatan-kegiatan sosial di lapangan bersama masyarakat }\end{array}$ \\
\hline $\begin{array}{l}\text { Kepeduliaan } \\
\text { terhadap sesama } \\
\text { dan lingkungan }\end{array}$ & $\begin{array}{l}\text { - kepedulian terhadap sesama warga } \\
\text { - kepedulian terhadap lingkungan, } \\
\text { - motivasi untuk memperhatikan dan membantu orang lain dan lingkungan }\end{array}$ \\
\hline
\end{tabular}




\section{Analisis Data}

\section{Penilaian Unsur Modal Sosial Masing-Masing Desa Penyangga}

Penilaian tingkatan unsur modal sosial masing-masing desa penyangga dilakukan dengan analisis deskriptif dengan menggunakan persamaan selang nilai (Supranto, 2000). Berdasarkan jumlah subunsur atau indikator yang dijadikan penilaian dari masing-masing unsur modal sosial maka selang nilai dari masing-masing tingkatan unsur modal sosial ditampilkan dalam Tabel 3.

Tabel 3. Selang Nilai Tingkatan Unsur Modal Sosial yang Dinilai di Lapangan

\begin{tabular}{|c|c|c|c|c|c|c|c|}
\hline \multirow[b]{2}{*}{ No } & \multirow[b]{2}{*}{ Unsur Modal sosial } & \multirow{2}{*}{$\begin{array}{c}\text { Selang Nilai } \\
(\mathbf{X m a x}-\mathbf{X} \text { Min }) \\
/ \mathbf{N}\end{array}$} & \multicolumn{5}{|c|}{$\begin{array}{l}\text { Selang Tingkatan unsur modal sosial } \\
\end{array}$} \\
\hline & & & $\begin{array}{l}\text { Sangat } \\
\text { Lemah }\end{array}$ & Lemah & Sedang & Kuat & $\begin{array}{c}\text { Sangat } \\
\text { Kuat }\end{array}$ \\
\hline 1 & Kepercayaan & $(60-12) / 5=9,6$ & $\leq 21$ & $22-31$ & $32-41$ & $42-51$ & $>51$ \\
\hline 2 & Norma & $(35-7) / 5=5,6$ & $\leq 12$ & $13-18$ & $19-24$ & $25-30$ & $>30$ \\
\hline 3 & Jaringan Sosial & $\begin{array}{r}(115-23) / 5= \\
18,4\end{array}$ & $\leq 41$ & $42-60$ & $61-79$ & $80-97$ & $>97$ \\
\hline 4 & Tindakan proaktif & $(20-4) / 5=3,2$ & $\leq 7$ & $8-10$ & $11-13$ & $14-16$ & $>16$ \\
\hline 5 & $\begin{array}{l}\text { kepeduliaan terhadap } \\
\text { sesama dan } \\
\text { lingkungan }\end{array}$ & $(15-3) / 5=2,4$ & $\leq 5$ & $6-8$ & $9-11$ & $12-13$ & $>13$ \\
\hline
\end{tabular}

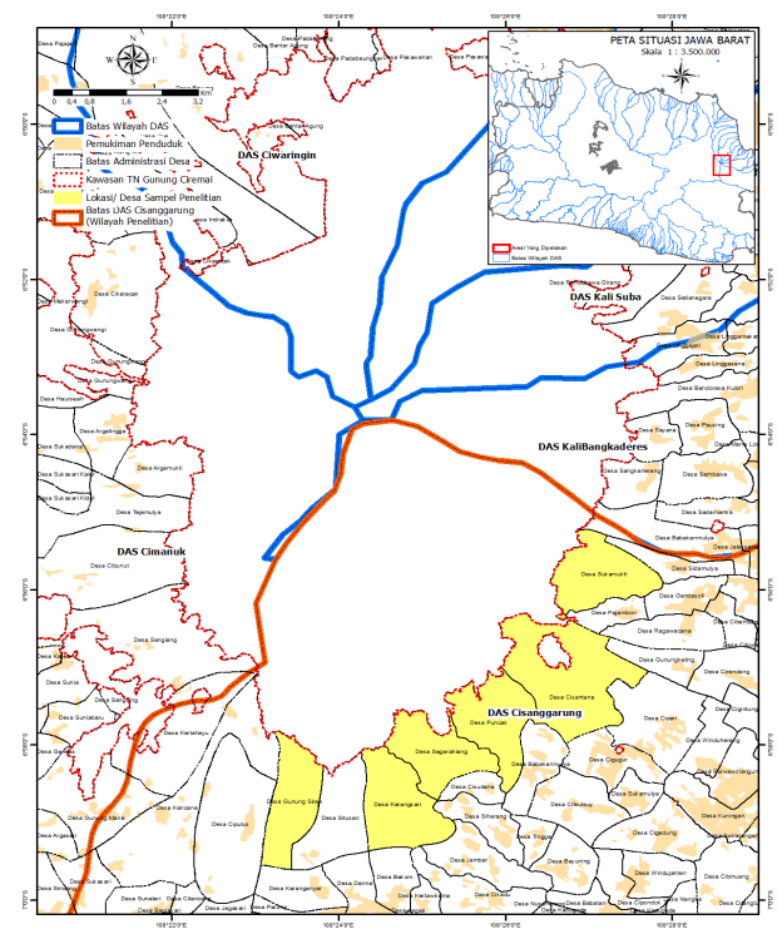

Sumber: BTNGC, BBWS, BPDASHL Cimanuk Citanduy, 2017

\section{Gambar 1. Peta Lokasi Penelitian}


Tingkatan modal sosial di masing-masing desa kajian di wilayah Hulu DAS Cisanggarung diperoleh dengan menjumlahkan nilai dari masing-masing unsur pembentuk modal sosial. Selanjutnya, berdasarkan persamaan selang, maka selang nilai untuk tingkatan modal sosial masyarakat penyangga TNGC di wilayah hulu DAS Cisanggarung berikut makna dari masing-masing tingkatan modal sosial terkait dengan kemitraan konservasi ditampilkan pada Tabel 4. Kategori tingkatan modal sosial yang dibentuk mengikuti konsep model sosial (Uphoff, 2000) yang dimodifikasi menjadi lima tingkatan modal sosial yaitu sangat lemah, lemah, sedang, kuat dan sangat kuat.

Tabel 4. Selang Nilai Tingkatan Modal Sosial yang Dinilai di Lapangan

\begin{tabular}{llrl}
\hline No & $\begin{array}{c}\text { Tingkatan Modal } \\
\text { Sosial }\end{array}$ & Selang Nilai & \multicolumn{1}{c}{ Makna Tingkatan Modal Sosial } \\
\hline 1 & Sangat Lemah & $\leq 88$ & $\begin{array}{l}\text { Sangat sulit untuk melakukan program pengembangan } \\
\text { kemitraan konservasi. }\end{array}$ \\
2 & Lemah & $89-128$ & $\begin{array}{l}\text { Sulit untuk melakukan program pengembangan } \\
\text { kemitraan konservasi } \\
\text { Mudah untuk melakukan program pengembangan } \\
\text { kemitraan konservasi tetapi diperlukan bantuan atau } \\
\text { usaha untuk memperkuat modal sosial }\end{array}$ \\
3 & Sedang & $129-168$ Mudah untuk melakukan program pengembangan \\
& Kuat & $169-207$ & $\begin{array}{l}\text { kemitraan konservasi } \\
\text { Sangat mudah untuk melakukan program } \\
\text { pengembangan kemitraan konservasi }\end{array}$ \\
\hline
\end{tabular}

\section{Analisis Hubungan Pengaruh Unsur Modal Sosial terhadap Modal Sosial di Wilayah DAS Cisanggarung}

Hubungan pengaruh masing-masing unsur modal sosial terhadap modal sosial di masing-masing desa kajian dilakukan dengan Confirmatory Factor Analysis, dengan menggunakan software SPSS 22 dan LISREL 7.8. Variabel laten yang digunakan adalah modal sosial $(\mathrm{Y})$, sedangkan variabel teramati adalah kepercayaan (X1), jaringan sosial (X2), norma sosial (X3), tindakan proaktif (X4), dan kepedulian terhadap sesama dan lingkungan (X5). Variabel unsur modal sosial berpengaruh nyata apabila t-value $\geq \mathrm{t}$ tabel. Nilai esimasi koefisien pengaruh atau loading factor menggambarkan konstribusi pengaruh, yaitu semakin besar nilainya maka konstribusi pengaruhnya semakin kuat (Wijayanto, 2008).

\section{Hasil dan Pembahasan}

\section{Penilaian Unsur-UnsurModal Sosial Masing-Masing Desa Penyangga}

\section{Kepercayaan}

Secara keseluruhan tingkatan unsur kepercayaan dari setiap desa kajian berada pada tingkatan sedang kecuali desa Karang sari yang berada pada tingkatan kuat (Tabel 5). Analisis terhadap dua belas subunsur kepercayaan diperoleh hasil, bahwa semua desa kajian memiliki tingkat kepercayaan yang kuat, terhadap sesama warga dalam satu desa, terhadap tokoh masyarakatnya (tokoh agama, tokoh adat) dan terhadap lembaga pemerintah (perangkat desa, Balai Taman Nasional Gunung Ciremai/BTNGC, Pemerintah Daerah Kabupaten Kuningan) kecuali Desa Gunung Sirah yang berada pada tingkat lemah untuk kepercayaan terhadap perangkat desa, dan Desa Cisantana yang berada pada tingkat sedang untuk kepercayaan terhadap BTNGC dan Pemerintah Daerah Kabupaten Kuningan. 


\section{Modal Sosial Masyarakat di Kawasan Penyangga Taman Nasional Gunung Ciremai ...}

Tingkatan kepercayaan desa kajian terhadap kelompok air dan tani, umumnya berada pada tingkatan kuat kecuali Desa Gunung Sirah yang berada pada tingkatan lemah terhadap kelompok air dan sedang terhadap kelompok tani, dan Desa Cisantana yang berada pada tingkatan sedang terhadap kelompok air dan tani. Tingkat kepercayaan terhadap kelompok wisata dari setiap desa kajian, umumnya berada pada tingkatan sedang, kecuali Desa Sagarahiang dan Puncak yang berada pada tingkatan kuat. Selanjutnya kepercayaan terhadap warga desa lain, warga dari etnis berbeda, dan perusahaan pemanfaat jasa lingkungan umumnya berada pada tingkat lemah sampai sedang.

Kuatnya kepercayaan masyarakat terhadap warga dalam satu desa, karena adanya kesamaan dalam hal garis keturunan, agama dan juga etnis. Sebagian besar anggota masyarakat beragama Islam dan bersuku budaya Sunda. Hasil ini sejalan dengan pernyataan dan temuan penelitian yang menyatakan bahwa kepercayaan individu salah satunya tumbuh dan dibangun atas dasar kesamaan garis keturunan dan kesamaan nilainilai identitas maupun kepentingan atau kebutuhan di antara individu yang selanjutnya kepercayaan antarindividu ini akan berkembang membangun kepercayaan sosial (Fukuyama, 2001; Roslinda, 2018; Roslinda, Ekyastuti, \& Kartikawati, 2017; Sukoco \& Hardi, 2013; Wartiharjono, 2017). Tingginya kepercayaan terhadap tokoh masyarakat dikarenakan tokoh masyarakat dinilai sebagai individu yang mampu bersifat jujur, mengayomi, konsisten memegang nilai kebenaran dan keadilan, serta memiliki pengetahuan dan pengalaman yang lebih, dalam ilmu agama dan adat istiadat. Hasil penelitian ini berbeda dengan hasil penelitian Oktadiyani et al. (2013) yang menyatakan bahwa tingkat kepercayaan masyarakat terhadap tokoh masyarakat adat di dua dusun di sekitar Taman Nasional Kutai, berada pada tingkatan sedang.

Kuatnya kepercayaan masyarakat terhadap petugas BTNGC dan Pemerintah Daerah Kabupaten Kuningan dikarenakan kedua lembaga tersebut dinilai memilki kinerja yang baik. Tingkat kepercayaan terhadap kelompok air, wisata dan tani sangat terkait dengan motivasi atau tujuan kelompok, proses awal pembentukan kelompok, sistem keanggotaan dan kinerja kelompok. Kelompok yang memiliki tujuan untuk kebaikan masyarakat, dibentuk melalui musyawarah bersama, sistem keanggotaan yang terbuka dan mempunyai kinerja yang bagus akan lebih dipercaya oleh masyarakat. Selanjutnya tidak kuatnya kepercayaan terhadap warga desa lain, perusahaan yang memanfaatkan potensi jasa lingkungan dan kepada warga dari etnis yang berbeda, disebabkan karena tingginya tingkat kehati-hatian masyarakat terhadap warga atau pihak di luar desanya yang belum mereka kenal. Kondisi ini mengakibatkan di lapangan masih ditemukan adanya konflik antardesa maupun dengan perusahaan, terutama dalam pemanfaatan air dari kawasan TNGC maupun pengelolaan wisata.

Penelitian ini menunjukkan bahwa unsur modal sosial kepercayaan merupakan salah satu unsur penting yang harus ada dalam proses pemanfaatan sumber daya alam dan membangun kerjasama di pedesaan. Kepercayaan akan memudahkan membangun kerjasama sehingga mengurangi persaingan dan konflik. Hasil ini sejalan dengan pendapat (Ostrom, 1990) yang menyatakan bahwa kepercayaan merupakan salah satu unsur modal sosial yang penting dalam pemanfaatan sumber daya alam yang sifatnya common pool resources, karena dengan kepercayaan akan mengurangi biaya-biaya transaksi dan juga konflik dalam pemanfaatan sumber daya alam. Selanjutnya sejalan pula dengan hasil penelitian Innah, Suharjito, Dharmawan, \& Darusman (2013) dan Saefulrahman (2015) yang menyatakan kepercayaan adalah komponen mendasar dari pembentukan modal sosial di daerah pedesaan, karena aspek lainnya (kerjasama, jaringan, kepemimpinan) tidak akan mapan jika tidak berdasarkan saling percaya antaranggota masyarakat. 


\section{$\underline{\text { Norma }}$}

Hampir semua desa kajian memiliki nilai unsur modal sosial norma berada pada tingkatan kuat, bahkan Desa Gunung Sirah berada pada tingkatan sangat kuat (Tabel 5). Selanjutnya semua sub unsur yang membangun norma sosial di semua desa kajianpun memiliki nilai tingkatan kuat, hanya sebagian kecil yang bernilai sedang, yaitu ketaatan terhadap norma kesopanan untuk Desa Cisantana dan Sukamukti serta menjaga kerukunan dalam kehidupan sehari-hari untuk Desa Puncak dan Cisantana. Berdasarkan pengamatan lapangan dan wawancara, norma agama merupakan norma yang paling banyak dipahami dan ditaati serta dijadikan pedoman dalam berinteraksi sosial di lapangan. Kuatnya tingkat ketaatan terhadap norma agama di semua desa kajian, tidak terlepas dari keyakinan dan kepercayaan warga bahwa norma agama merupakan norma yang sumbernya langsung dari Sang Pencipta, yang mempunyai kebenaran mutlak. Selain itu tidak terlepas dari tingkat kepercayaan warga terhadap tokoh agama yang tinggi.

Semua desa kajian masih memiliki norma adat yang mengatur perlindungan dan pemanfaatan sumber daya alam serta memiliki tingkat ketaatan yang masih tinggi terhadap norma adat tersebut. Norma-norma adat tersebut beberapa memiliki kesamaan, di antaranya yaitu masih adanya larangan untuk tidak merusak tempat-tempat yang merupakan sumber mata air, baik di kawasan TNGC maupun di luar kawasan TNGC. Bahkan di Desa Gunung Sirah, Sagarahiang, dan Puncak, masih terdapat tata cara adat apabila akan memanfaatkan salah satu sumber air di kawasan hutan.

Aktualisasi nilai-nilai adat, kesusilaan, kesopanan dan kerukunan dalam kehidupan sehari-hari, sangat dipengaruhi oleh nilai-nilai Agama Islam dan juga Budaya Sunda sebagai agama dan budaya dominan masyarakat penyangga TNGC. Hasil penelitian ini sejalan dengan hasil kajian Prayogi \& Danial (2016) yang menyatakan bahwa nilai-nilai yang terdapat pada kebudayaan seiring dengan berjalannya waktu akan mempengaruhi dan membentuk aturan-aturan dalam bertindak dan bertingkah laku masyarakatnya, yang selanjutnya akan membentuk pola-pola kebudayaan. Selanjutnya tingkat pemahaman dan ketaatan terhadap peraturan pemerintah bidang pengelolaan dan pemanfaatan sumber daya alam, tidak terlepas dari peran dan sosialisasi pihak BTNGC dan Pemerintah Daerah Kabupaten Kuningan kepada masyarakat dan juga tingkat kepercayaan masyarakat terhadap dua lembaga pemerintah tersebut.

Penelitian ini menunjukkan bahwa penerapan norma tidak terlepas dari tingkat kepercayaan dan pemahaman masyarakat terhadap nilai-nilai yang ada dalam norma itu sendiri dan juga kepada orang atau lembaga yang memimpin dan mensosialisasikan norma tersebut (tokoh adat, agama, lembaga pemerintah). Dengan norma akan terbentuk pola hubungan dan interaksi sosial dalam masyarakat dan juga dengan lingkungannya. Norma agama merupakan norma yang paling berpengaruh diantara norma-norma lainnya bagi masyarakat. Sehingga penguatan pemahaman dan ketaatan terhadap norma agama harus menjadi prioritas di semua desa kajian. Temuan ini sejalan dengan pendapat Fukuyama (2001) bahwa nilai-nilai agama dan budaya yang telah dipercayai dan diterapkan masyarakat selanjutnya akan ditransmisikan dari satu generasi ke generasi berikutnya melalui peran tokoh agama dan adat. Selanjutnya akan membangun sebuah karakteristik pola perilaku dan budaya sebagai sebuah ciri khas modal sosial masyarakat.

\section{Jaringan Sosial}

Nilai tingkat jaringan sosial di masing-masing desa kajian secara umum berada pada tingkatan sedang dan kuat. Desa Gunung Sirah, Karang sari, dan Cisantana berada pada tingkatan sedang, sedangkan tiga desa lainnya berada tingkatan kuat (Tabel 5). Sub unsur kepadatan jaringan masing-masing desa kajian berdasarkan tingkat keterlibatan masyarakat untuk menjadi anggota dalam organisasi yang ada di desa, semuanya berada pada 
tingkatan sedang. Jumlah organisasi yang diikuti responden rata-rata hanya dua organisasi, kecuali Desa Sagarahiang dan Desa Puncak rata-rata tiga organisasi. Organisasi yang paling banyak diikuti oleh masyarakat di seluruh desa kajian adalah kelompok pengajian dan kelompok air. Untuk kelompok wisata, tani dan kepemudaan, berada pada level lemah sedang. Tingginya keterlibatan masyarakat pada kelompok pengajian dan air, disebabkan karena masih kuatnya ketaatan masyarakat terhadap nilai-nilai agama serta menganggap bahwa kelompok pengajian mampu memberikan manfaat lebih berupa ilmu agama. Begitu juga dengan kelompok air yang mampu memberikan manfaat berupa terpenuhinya kebutuhan air masyarakat. Selain itu, kedua kelompok tersebut memiliki sistem keanggotaan kelompok yang terbuka dan juga adanya kepercayaan masyarakat pada pengurus kedua kelompok tersebut.

Tingkat keragaman jaringan ditunjukkan dengan adanya sistem kepengurusan dan keanggotaan kelompok yang sudah mewakili semua lapisan masyarakat. Hal ini sangat ditentukan oleh sistem keanggotaan kelompok dan kepercayaan masyarakat. Kelompok yang bersifat terbuka dan dipercaya oleh masyarakat akan memiliki keragaman kelompok yang lebih tinggi. Kelompok pengajian dan kepemudaan memiliki nilai keragaman jaringan pada tingkatan kuat untuk semua desa kajian. Kelompok air memiliki nilai keragaman jaringan pada tingkatan kuat untuk Desa Karangsari, Sagarahiang, Sukamukti, dan Puncak serta tingkatan sedang untuk Desa Gunung Sirah dan Cisantana. Selanjutnya nilai keragaman jaringan kelompok tani dan wisata, di masing-masing desa kajian berada pada tingkatan sedang dan kuat.

Motivasi atau kerelaan masyarakat untuk membangun jaringan sosial, tidak sepenuhnya atas keinginan pribadi, tetapi juga ada dorongan atau ajakan orang lain atau kelompok atau juga pemerintah. Partisipasi atau keaktifan masyarakat dalam memelihara keutuhan dan kebersamaan jaringan sosial baik antarindividu masyarakat maupun sebagai anggota kelompok, diwujudkan dalam bentuk selalu menjaga hubungan baik dan menghindari terjadinya konflik, aktif dalam setiap kegiatan kelompok serta menaati aturan yang ada dalam kelompok. Musyawarah mufakat merupakan pilihan pertama untuk penyelesaian konflik. Selanjutnya kemudahan akses terhadap informasi dan komunikasi sangat menentukan tingkat kerjasama warga, baik di dalam maupun dengan luar komunitas.

Kuatnya tingkat kerjasama antar sesama warga maupun antar kelompok dalam satu komunitas (dalam satu desa) dibanding dengan tingkat kerjasama ke luar komunitasnya disebabkan karena masyarakat lebih percaya kepada anggota masyarakat dalam satu desa, yang telah mereka kenal lama, memiliki kesamaan etnis, pengalaman sosial, agama, wilayah, dan ikatan kekeluargaan. Sehingga model jaringan sosial yang terbentuk lebih dominan bersifat kekerabatan, terbatas lokal desa dan memiliki ikatan yang sangat kuat. Hal ini sejalan dengan hasil penelitian Oja \& Serano (2016) bahwa jaringan sosial yang terbentuk atas dasar keturunan, pengalaman sosial dan kesamaan kepercayaan dan agama cenderung akan membentuk jaringan dengan kohesifitas yang tinggi namun memiliki rentang jaringan maupun kepercayaan yang sempit. Berbeda dengan kelompok yang membangun jaringan dengan dasar kesamaan orientasi dan tujuan serta dikelola dengan pola organisasi yang modern akan memiliki rentang jaringan yang lebih luas.

Hasil penilaian unsur modal sosial jaringan sosial ini menunjukkan bahwa kepercayaan merupakan salah satu faktor yang paling mendasari anggota masyarakat dalam berinteraksi dan membangun kerjasama baik antar individu maupun dengan dan dalam kelompok. Masyarakat akan memilih dan menentukan dengan individu dan kelompok sosial mana mereka akan melakukan jaringan sosialnya. Hasil ini sejalan dengan hasil penelitian Qurniati, Febryano, \& Zulfiani (2017), yang menyatakan bahwa kepercayaan merupakan faktor penting untuk memperkuat modal sosial dalam kelompok tani agroforestri, yang salah satunya dibangun melalui aksi kolektif anggota dalam 
kelompok serta dengan meningkatkan jaringan yang baik. Selanjutnya sejalan pula dengan pernyataan Pranadji (2006) bahwa hubungan saling percaya antara anggota masyarakat akan berkembang membentuk kekuatan kerjasama dan jaringan di masyarakat.

\section{$\underline{\text { Tindakan Proaktif }}$}

Nilai tingkatan unsur modal sosial tindakan proaktif masing-masing desa kajian semuanya berada pada kategori kuat, kecuali Desa Gunung Sirah yang berada pada kategori lemah (Tabel 5). Hampir semua sub unsur tindakan proaktif yang diukur di lapangan di semua desa kajian memiliki nilai tingkatan kuat, kecuali untuk sub unsur tindakan inovatif di Desa Puncak dan Cisantana berada pada tingkatan sedang. Untuk Desa Gunung Sirah semua nilai sub unsur tindakan proaktifnya berada pada tingkatan lemah. Berdasarkan pengamatan lapangan dan wawancara salah satu faktor yang menjadi dorongan munculnya tindakan proaktif masyarakat adalah tingkat kepercayaan terhadap pemerintah desa dan kemampuannya dalam mensosialisasikan setiap program pembangunan desa. Hasil ini sejalan dengan hasil penelitian yang menyatakan bahwa kepercayaan institusional salah satunya berpengaruh terhadap perilaku lingkungan, tindakan-tindakan partisipasi dan penerimaan setiap isu dan kebijakan atau norma oleh masyarakat (Groothuis \& Miller, 1997; Nikoleta Jones, Malesios, \& Botetzagias, 2009; Petts, 1998).

Kegiatan inovatif untuk lingkungan dan masyarakat di Desa Karangsari, Sagarahiang dan Sukamukti salah satunya ditunjukkan dengan sudah terbangunnya sistem pengelolaan pemanfaatan air dengan sistem water meter dan pengelolaan objek wisata alam yang dikelola oleh kelompok masyarakat. Untuk Desa Puncak dan Cisantana mekanisme pengaturan pemanfaatan air belum memakai sistem water meter, tetapi objek wisata yang dikelola oleh kelompok masyarakat sudah ada. Insiatif secara pribadi untuk memelihara dan memperbaiki sarana prasarana umum dan lingkungan ditunjukkan salah satunya melalui adanya insiatif dari individu masyarakat untuk mengecek dan memperbaiki sarana prasarana saluran air berupa pipa air dan parit apabila rusak atau tersumbat. Keaktifan menghadiri dan memberikan pendapat dalam pertemuan desa ditunjukkan dengan banyaknya warga masyarakat yang hadir dalam setiap musyawarah desa untuk kepentingan pembangunan desa. Selanjutnya keaktifan individu dalam bidang sosial di lapangan ditunjukkan dengan tindakan proaktif masyarakat untuk ikut terlibat dalam pelaksanaan program pembangunan desa, misal pembuatan atau perbaikan jalan kampung, tempat peribadatan, pendidikan dan sarana prasarana lingkungan lainnya.

\section{Kepedulian Terhadap Sesama dan Lingkungan}

Nilai tingkatan sub unsur dan unsur modal sosial kepedulian terhadap sesama dan lingkungan di setiap desa kajian umumnya berada pada kategori kuat sampai sangat kuat (Tabel 5). Desa Gunung Sirah dan Sagarahiang memiliki tingkatan yang sangat kuat sedangkan yang lainnya berada pada tingkatan kuat. Berdasarkan pengamatan lapangan dan wawancara, salah satu faktor penyebab kuatnya tingkatan sub unsur maupun unsur kepedulian terhadap sesama dan lingkungan adalah karena masih dipegangnya normanorma keagamaan dan norma kesusilaan dan kesopanan di masyarakat. Tolong menolong, gotong royong dan menjaga lingkungan merupakan anjuran agama dan bagian dari nilainilai adat istiadat, sebagai salah satu bentuk amal kebaikan untuk menjaga hubungan harmonis antara manusia dan juga Tuhan.

Berdasarkan hal tersebut, penelitian ini menemukan bahwa ketaatan terhadap norma agama, norma kesusilaan dan norma kesopanan dapat mendorong dan terpeliharanaya sikap kepedulian dan solidaritas antar sesama warga dan lingkungan, sehingga akan melahirkan modal sosial yang kuat dalam masyarakat. Hasil ini sejalan dengan pendapat 


\section{Modal Sosial Masyarakat di Kawasan Penyangga Taman Nasional Gunung Ciremai ...}

Bauto (2014) yang menyatakan bahwa agama dengan segala nilai dan norma yang dikandungnya akan memberikan pedoman bagi manusia untuk berfikir dan bertindak baik dengan sesama manusia maupun dengan lingkungannya, untuk menciptakan kehidupan yang harmonis dan damai. Selanjutnya segala hasil fikiran dan tindakan manusia yang menjadi kebiasaan dan disepakati diantara kelompok manusia akan melahirkan norma dan budaya masyarakat. Hasil penenlitian ini sejalan pula dengan pernyataan dan hasil penelitian Anderson (2003) dan Jones et al. (2009) yang menyataan bahwa kepatuhan terhadap norma-norma sosial dapat dianggap sebagai salah satu parameter penting yang mempengaruhi perilaku individu dan warga masyarakat yang bertanggung jawab terhadap lingkungan, selain itu di lain pihak dapat mendorong pula terhadap tingkat kepatuhan terhadap kebijakan lingkungan.

\section{Tingkatan Modal Sosial Masyarakat Penyangga TNGC}

Berdasarkan Tabel 5, empat desa penyangga TNGC di wilayah Hulu DAS Cisanggarung memiliki tingkatan modal sosial yang kuat yaitu Desa Karangsari, Sagarahiang, Puncak dan Sukamukti dan dua desa lainnya memiliki tingkatan sedang yaitu Desa Gunung Sirah dan Cisantana. Secara keseluruhan modal sosial masyarakat di kawasan penyangga TNGC di Hulu DAS Cisanggarung berada pada tingkatan kuat, dengan jumlah total skor 41.586 dan rata-rata skor 174,33. Makna tingkatan modal sosial kuat untuk Desa Karangsari, Sagarahiang, Puncak dan Sukamukti mengacu pada kategori dan konsep model sosial Uphoff (2000) dikaitkan dengan program kemitraan konservasi, yaitu bahwa implementasi pengelolaan kawasan TNGC berbasis kemitraan di keempat desa tersebut dimungkinkan dapat berjalan lancar, dengan tetap masih perlunya upaya-upaya mempertahankan sub unsur-sub unsur modal sosial yang sudah kuat dan meningkatkan sub unsur yang masih berada pada posisi lemah dan sedang. Sedangkan makna tingkatan modal sosial sedang untuk Desa Gunung Sirah dan Cisantana yaitu pengelolaan Taman Nasional berbasis kemitraan di dua desa ini ke depannya akan membutuhkan upaya yang lebih intensif, terutama pada perbaikan point-point sub unsur modal sosial yang berada pada level lemah dan sedang, sehingga diharapkan bisa naik menjadi kuat bahkan sangat kuat. Selanjutnya makna tingkatan modal sosial kuat untuk seluruh wilayah Hulu DAS Cisanggarung pada dasarnya menunjukkan gambaran atau kualitas tingkatan modal sosial di seluruh wilayah hulu DAS Cisanggarung. Akan tetapi, nilai ini bukan berarti semua desa di wilayah Hulu DAS Cisanggarung tersebut memiliki tingkatan modal sosial yang kuat, karena pada kenyataannya ada 2 desa memiliki tingkatan sedang, yaitu Desa Gunung Sirah dan Cisantana.

\section{Hubungan Pengaruh Unsur-Unsur Modal Sosial Terhadap Modal Sosial Masyarakat TNGC}

Berdasarkan hasil confirmatory factor analysis (Tabel 6) menunjukkan bahwa hampir semua unsur modal sosial berpengaruh nyata terhadap pembentukan modal sosial di semua desa kajian. Hanya unsur kepercayaan yang tidak berpengaruh terhadap modal sosial di Desa Gunung Sirah dan unsur tindakan pro aktif untuk Desa Sukamukti. Selanjutnya unsur modal sosial yang paling berpengaruh terhadap pembentukan modal sosial setiap desa (dilihat dari nilai loading faktor/LF) dapat dikelompokkan menjadi tiga kelompok, yaitu Desa Gunung Sirah unsur modal sosial yang paling berpengaruhnya adalah norma, Desa Sagarahiang unsur modal sosial yang paling berpengaruhnya adalah tindakan proaktif dan Desa Karangsari, Puncak, Cisantana dan Sukamukti memiliki unsur modal sosial yang paling berpengaruh yang sama yaitu jaringan sosial. Selanjutnya untuk unsur modal sosial yang paling berpengaruh secara keseluruhan terhadap pembentukan modal sosial masyarakat di wilayah Hulu DAS Cisanggarung adalah jaringan sosial. 
Tabel 5. Tingkatan Unsur Modal Sosial Masyarakat Masing-Masing Desa Kajian

\begin{tabular}{|c|c|c|c|c|c|c|c|c|c|c|c|c|c|}
\hline \multirow[b]{2}{*}{ No } & \multirow{2}{*}{$\begin{array}{l}\text { Unsur } \\
\text { modal } \\
\text { sosial }\end{array}$} & \multicolumn{2}{|c|}{1} & \multicolumn{2}{|c|}{2} & \multicolumn{2}{|c|}{3} & \multicolumn{2}{|r|}{4} & \multicolumn{2}{|c|}{5} & \multicolumn{2}{|c|}{6} \\
\hline & & Skor & $\begin{array}{l}\text { Rata- } \\
\text { rata }\end{array}$ & Skor & $\begin{array}{c}\text { Rata- } \\
\text { rata }\end{array}$ & Skor & $\begin{array}{l}\text { Rata- } \\
\text { rata }\end{array}$ & Skor & $\begin{array}{l}\text { Rata- } \\
\text { rata }\end{array}$ & Skor & $\begin{array}{l}\text { Rata- } \\
\text { rata }\end{array}$ & Skor & $\begin{array}{c}\text { Rata- } \\
\text { rata }\end{array}$ \\
\hline 1 & Kepercayaan & 1135 & $\begin{array}{r}37,83 \\
\approx 3\end{array}$ & 1290 & $43 \approx 4$ & 1926 & $\begin{array}{r}40,98 \\
\quad \approx 3\end{array}$ & 1614 & $\begin{array}{r}40,35 \approx \\
3\end{array}$ & 2268 & $\begin{array}{r}37,18 \approx \\
3\end{array}$ & 1275 & $\begin{array}{r}41,13 \\
\quad \approx 3\end{array}$ \\
\hline 2 & Norma & 932 & $\begin{array}{r}31,07 \\
\approx 5\end{array}$ & 824 & $\begin{array}{r}27,47 \\
\quad \approx 4\end{array}$ & 1353 & $\begin{array}{r}28,79 \\
\approx 4\end{array}$ & 1105 & $\begin{array}{r}27,63 \approx \\
4\end{array}$ & 1596 & $\begin{array}{r}26,16 \approx \\
4\end{array}$ & 818 & $\begin{array}{r}26,39 \\
\approx 4\end{array}$ \\
\hline 3 & $\begin{array}{l}\text { Jaringan } \\
\text { Sosial }\end{array}$ & 2235 & $\begin{array}{r}74,51 \\
\approx 3\end{array}$ & 2352 & $\begin{array}{r}78,39 \\
\approx 3\end{array}$ & 3756 & $\begin{array}{l}79,91 \\
\quad \approx 4\end{array}$ & 3215 & $\begin{array}{r}80,39 \approx \\
4\end{array}$ & 4761 & $\begin{array}{r}78,05 \approx \\
3\end{array}$ & 2605 & $\begin{array}{r}84,03 \\
\approx 4\end{array}$ \\
\hline 4 & $\begin{array}{l}\text { Tindakan } \\
\text { proaktif }\end{array}$ & 240 & $\begin{array}{r}8,00 \\
\approx 2\end{array}$ & 450 & $\begin{array}{l}15 \\
\approx 4\end{array}$ & 751 & $\begin{array}{r}15,98 \\
\approx 4\end{array}$ & 589 & $\begin{array}{r}14,73 \approx \\
4\end{array}$ & 859 & $\begin{array}{r}14,08 \approx \\
4\end{array}$ & 480 & $\begin{array}{r}15,48 \\
\quad \approx 4\end{array}$ \\
\hline 5 & $\begin{array}{l}\text { Kepedulian } \\
\text { terhadap } \\
\text { sesama dan } \\
\text { lingkungan }\end{array}$ & 411 & $\begin{array}{r}13,70 \\
\approx 5\end{array}$ & 395 & $\begin{array}{r}13,17 \\
\approx 4\end{array}$ & 658 & $14 \approx 5$ & 526 & $\begin{array}{r}13,15 \approx \\
4\end{array}$ & 764 & $\begin{array}{r}12,52 \approx \\
4\end{array}$ & 403 & $13 \approx 4$ \\
\hline & Total & 4953 & $\begin{array}{r}165,1 \\
\approx 3\end{array}$ & 5311 & $\begin{array}{r}177,03 \\
\approx 4 \\
\end{array}$ & 8444 & $\begin{array}{r}179,66 \\
\approx 4\end{array}$ & 7049 & $\begin{array}{r}176,25 \approx \\
4\end{array}$ & 10248 & $\begin{array}{r}167,99 \approx \\
3\end{array}$ & 5581 & $\begin{array}{r}180,03 \\
\approx 4\end{array}$ \\
\hline
\end{tabular}

Keterangan: 1= Gunung Sirah; 2= Karangsari; 3= Sagarahiang; 4= Puncak; 5= Cisantana; 6= Sukamukti

Hasil penelitian ini secara keseluruhan menunjukkan bahwa walaupun dalam satu satuan ekosistem yang sama (Hulu DAS Cisanggarung), modal sosial masyarakat tiap desa memiliki karakteristik yang bervariasi. Hal ini dibuktikan dengan karakteritik tingkatan sub unsur dan unsur modal sosial serta unsur modal sosial yang berpengaruh terhadap pembentukan modal sosial tiap-tiap desa berbeda. Sehingga implikasinya terhadap penyusunan skema kemitraan konservasi di tiap desa juga akan berbeda, walalupun berada dalam satuan DAS yang sama. Untuk kepentingan penyusunan dan implementasi skema kemitraan konservasi, maka yang terpenting untuk diperhatikan adalah pada nilai poinpoint sub unsur modal sosial yang membangun modal sosial di tiap-tiap desa tersebut. Hal ini karena wilayah desa adalah unit administrasi terkecil untuk diimplementasikannya program-program pengelolaan kawasan konservasi berbasis kemitraan.

Hasil penelitian ini secara substansi dan cara pandang penelitian, berbeda dengan hasil penelitian Roslinda (2018) yang menilai modal sosial masyarakat pada tingkat seluruh kawasan Taman Nasional Danau Sentarum (TNDS), yang dibangun dengan menilai persefsi responden yang sampelnya diambil dari tingkat wilayah seksi pengelolaan. Analisa modal sosial yang digunakan adalah analisa gabungan seluruh wilayah, bukan analisa per desa atau perseksi wilayah dengan hasil penelitian menunjukkan bahwa tingkat modal sosial masyarakat di kawasan TNDS masih tinggi/kuat. Selanjutnya berbeda dengan Oktadiyani et al. (2013), yang penelitiannya dilakukan pada satuan dusun di dua desa tanpa batasan satuan ekosistem dan fokus untuk kepentingan pengembangan ekoswisata. Selanjutnya, hasil penelitian ini berbeda pula dengan hasil penelitian Sulistyorini et al. (2018) yang menilai modal sosial masyarakat di wilayah areal penggunaan lain yang berbatasan dengan kawasan Taman Nasional Kutai (TNK) untuk kepentingan pemanfaatan mangrove untuk program sylvofishery. Penelitian Sulistyorini et al. (2018) dibangun dengan menilai persepsi responden dari lima desa sampel, tetapi penekanan analisis modal sosial lebih ditujukan pada seluruh komunitas seluruh kawasan, dan belum membahas potensi lainnya yang ada di wilayah penelitian yang bisa dikembangkan untuk program pemberdayaan selain sylvofishery. Selanjutnya sub unsur dan unsur modal sosial yang digunakan dalam penenlitia-pennelitian tersebut berbeda dengan pennelitaian ini. Penelitian ini ingin mencoba memmasukkan atau mengidentifikasi semua sub unsur, mulai stakeholder, norma, potensi desa, asehingga bisa diidentifikasi kekuatan sub unsur dan bidang kemitraan yang akan muncul dalam skema kemitraan konservasi.

Hasil penelitian ini merekomendasikan pentingnya kehati-hatian dalam menetapkan sampel desa penelitian apabila ingin menilai tingkatan modal sosial maupun mengevaluasi 


\section{Modal Sosial Masyarakat di Kawasan Penyangga Taman Nasional Gunung Ciremai ...}

pengaruh modal sosial terhadap program pengelolaan kawasan konservasi untuk seluruh kawasan, baik di kawasan TNGC maupun di kawasan konservasi lainnya. Khusus untuk kawasan TNGC, kedepannya penting dilakukan penelitian lanjutan untuk menilai karakteristik modal sosial pada ekosistem DAS lainnya (Kalibangkaderes, Kalisuba, Cipager, Ciwaringin, Cilutung, Cimanuk) serta penilaian hubungan modal sosial dengan karakteristik biofisik yang ada di masing-masing DAS. Hal ini diperlukan demi tepatnya penyusunan dan evaluasi program pengelolaan kawasan TNGC berbasis ekosistem DAS sehingga dapat dihubungkan antara karakteristik ekosistem dengan karakteristik sosialnya, seperti, penyusunan zonasi, Rencana Pengelolaan Taman Nasional maupun program kemitraan konservasi.

Tabel 6. Hubungan Pengaruh Unsur-Unsur Modal Sosial terhadap Modal Sosial di Masing-Masing Desa Kajian

\begin{tabular}{|c|c|c|c|c|c|c|c|c|c|c|c|c|c|c|}
\hline \multirow{2}{*}{$\begin{array}{c}\text { Unsur } \\
\text { Modal } \\
\text { Sosial }\end{array}$} & \multicolumn{2}{|c|}{1} & \multicolumn{2}{|c|}{2} & \multicolumn{2}{|c|}{3} & \multicolumn{2}{|c|}{4} & \multicolumn{2}{|c|}{5} & \multicolumn{2}{|c|}{6} & \multicolumn{2}{|c|}{ Total } \\
\hline & LF & $\begin{array}{c}\text { T- } \\
\text { Hit }\end{array}$ & LF & $\begin{array}{c}\text { T- } \\
\text { Hit }\end{array}$ & LF & $\begin{array}{c}\text { T- } \\
\text { Hit }\end{array}$ & LF & $\begin{array}{c}\text { T- } \\
\text { Hit }\end{array}$ & LF & $\begin{array}{c}\text { T- } \\
\text { Hit }\end{array}$ & LF & $\begin{array}{c}\text { T- } \\
\text { Hit }\end{array}$ & $\mathbf{L F}$ & $\begin{array}{l}\text { T- } \\
\text { Hit }\end{array}$ \\
\hline Norma & 1.00 & 6.82 & 0.86 & 5.34 & 0.90 & 5.16 & 0.64 & 3.31 & 0.63 & 3.81 & 0.54 & 2.97 & 0,84 & 15,24 \\
\hline Kepercayaan & 0.66 & 5.61 & 0.64 & 2.61 & 0.32 & 2.39 & 0.72 & 3.39 & 0.67 & 1.99 & 0.56 & 3.02 & 0,65 & 9,61 \\
\hline $\begin{array}{l}\text { Jaringan } \\
\text { sosial }\end{array}$ & 0.90 & 6.63 & 0.95 & 5.37 & 0.94 & 3.26 & 0.85 & 4.07 & 0.85 & 9.93 & 0.95 & 7.18 & 0,95 & 19,69 \\
\hline $\begin{array}{l}\text { Tindakan } \\
\text { proaktif }\end{array}$ & - & - & 0.88 & 5.00 & 0.95 & 8.82 & 0.80 & 3.51 & 0.67 & 2.37 & 0.79 & 2.49 & 0,56 & 8,98 \\
\hline $\begin{array}{l}\text { Kepedulian } \\
\text { sosial }\end{array}$ & 0.99 & 6.82 & 0.34 & 2.25 & 0.68 & 3.88 & 0.65 & 5.17 & 0.74 & 5.02 & - & - & 0,51 & 8,95 \\
\hline
\end{tabular}

Keterangan: 1= Gunung Sirah; 2= Karangsari; 3= Sagarahiang; 4= Puncak; 5= Cisantana; 6= Sukamukti

\section{Implikasi terhadap Implementasi Pengelolaan Kawasan Konservasi Berbasis Kemitraan}

Hasil penelitian ini memberikan indikasi dibutuhkannya skema pengelolaan TNGC berbasis kemitraan per desa dan per ekosistem. Dalam penyusunan skema kemitraan pada tingkat desa, sub unsur modal sosial yang berada pada level sangat kuat dan kuat, serta unsur modal sosial yang paling berpengaruh dalam pembentukan modal sosial tiap desa, harus menjadi pertimbangan utama. Selanjutnya perlu disusun juga program dalam usaha peningkatan modal sosial tiap desa dengan fokus pada sub unsur modal sosial yang berada pada tingkatan lemah dan sangat lemah.

Desa yang memiliki tingkatan modal sosial kuat, yaitu Desa Karangsari, Sagarahiang, Puncak dan Sukamukti, bidang kemitraan konservasi yang sebaiknya menjadi pilihan utama adalah bidang jasa lingkungan air, hal ini dikarenakan tingginya kepercayaan masyarakat terhadap kelompok air, serta kepadatan dan keragaman jaringan untuk kelompok air di empat desa tersebut berada pada kategori kuat. Selain itu ke empat desa tersebut di lapangan memiliki sumber air baik di dalam kawasan TNGC maupun di luar kawasan dengan debit dan ketersediaan yang lumayan tinggi. Selanjutnya dalam implementasinya maka faktor yang paling berpengaruh dalam pembentukan modal sosial tiap desa harus menjadi perhatian utama, sehingga diharapkan program kemitraan tersebut dapat berjalan lancer dan berhasil.

Desa yang memiliki tingkatan modal sosial sedang yaitu Desa Gunung Sirah dan Cisantana, bidang kemitraan konservasi yang sebaiknya menjadi pilihan utama adalah bidang pertanian dan wisata untuk Desa Gunung Sirah dan jasa lingkungan air serta wisata untuk Desa Cisantana. Namun dalam implementasinya, harus diikuti usaha yang intensif karena tingkatan modal sosial berada pada level sedang, yaitu dengan cara memelihara dan meningkatkan norma sosial untuk Desa Gunung Sirah dan jaringan sosial untuk Desa Karang Sari. 


\section{Kesimpulan}

Modal sosial masyarakat di desa-desa penyangga TNGC walaupun berada dalam satu ekosistem DAS yang sama (hulu DAS Cisanggarung) menunjukkan karakteristik yang bervariasi. Desa Gunung Sirah dan Cisantana memiliki kategori modal sosial sedang. Desa Karangsari, Sagarahiang, Puncak, dan Sukamukti memiliki kategori modal sosial kuat. Unsur modal sosial yang paling berpengaruh terhadap pembentukan modal sosial di setiap wilayah pedesaan juga memperlihatkan perbedaan. Norma sosial menjadi unsur yang paling berpengaruh di Desa Gunung Sirah, nilai tindakan pro-aktif menjadi unsur paling berpengaruh di Desa Sagarahiang, dan jaringan sosial menjadi unsur yang paling berpengaruh di Desa Karangsari, Cisantana, Puncak, dan Sukamukti. Gabungan dari nilai tingkatan modal sosial tiap desa merupakan nilai modal sosial pada tingkat wilayah ekosistem DAS Cisanggarung, yang nilainya menunjukkan kategori kuat, dengan unsur modal sosial yang paling berpengaruh adalah jaringan sosial. Penelitian ini menujukkan bahwa pada satuan ekosistem DAS yang sama, karakteristik sosial masyarakat (dalam hal ini modal sosial) belum tentu memiliki karakteristik yang sama. Sehingga, untuk menilai tingkatan modal sosial pada satuan wilayah atau ekosistem yang luas yang terdiri dari banyak desa, maka perlu kehati-hatian dalam pengambilan contoh sampel komunitasnya atau desanya. Hasil penelitian ini berkontribusi dalam bidang kemitraan di kawasan TNGC yaitu informasi karakteristik subunsur dan unsur modal sosial di setiap desa, terutama yang berada pada tingkatan kuat dan yang paling berpengaruh dapat dipertimbangkan dalam penyusunan skema kemitraan konservasi maupun peningkatan kualitas modal sosial masyarakat setiap desa.

\section{Daftar Pustaka}

Anderson, J. E. (2003). Public policy making: An introduction. Boston: Houghton Mifflin Company.

Asari, A., Toloh, B. H., \& Sangari. (2014). Pengembangan ekowisata bahari berbasis masyarakat di Desa Bahoi, Kecamatan Likupang Barat, Kabupaten Minahasa Utara. Jurnal Ilmiah Platax, 2(1), 25-32.

Asdak, C. (2002). Hidrologi dan pengelolaan daerah aliran sungai. Yogyakarta: Gadjah Mada University Press.

Balai Taman Nasional Gunung Ciremai. (2015). Review rencana pengelolaan taman nasional Gunung Ciremai tahun 2016 - 2025. BTNGC. Kuningan: BTNGC.

Barnes-Mauthe, M., Gray, S. A., Arita, S., Lynham, J., \& Leung, P. S. (2014). What determines social capital in a social-ecological system? Insights from a network perspective. Environmental Management, 55(2), 392410. doi:10.1007/s00267-014-0395-7.

Barnes-Mauthe, M., Oleson, K. L. L., Brander, L. M., Zafindrasilivonona, B., Oliver, T. A., \& van Beukering, P. (2015). Social capital as an ecosystem service: Evidence from a locally managed marine area. Ecosystem Services, 16(November), 283-293. doi:10.1016/j.ecoser.2014.10.009.

Bauto, L. M. (2014). Perspektif agama dan kebudayaan dalam kehidupan masyarakat Indonesia (Suatu tinjauan sosiologi agama). JPIS, Jurnal Pendidikan Ilmu Sosial, 23(2), 11-25.

Bisung, E., Elliott, S. J., Schuster-Wallace, C. J., Karanja, D. M., \& Bernard, A. (2014). Social capital, collective action and access to water in rural Kenya. Social Science and Medicine, 119, 147-154. doi:10.1016/j.socscimed.2014.07.060.

Budiaji, W. (2013). Skala pengukuran dan jumlah respon skala likert. Ilmu Pertanian dan Perikanan, 2(2), 127133.

Direktorat Konservasi Kawasan. (2018). Buku kemitraan konservasi. (A. Supriyanto, B. Sya'bani, A. Paramita, \& Syaiful, Eds.). Jakarta: Direktorat Kawasan Konservasi.

Effendi, A. D., Barkey, R. A., \& Jamil, M. H. (2014). Strategi pengembangan program pemberdayaan masyarakat pada model desa konservasi di Taman Nasional Taka Bonerate. Jurnal Sains \& Teknologi, 14(2), 151161.

Fukuyama, F. (2001). Social capital, civil society and development. Third World Quarterly, 22(1), 7-20. 


\section{Modal Sosial Masyarakat di Kawasan Penyangga Taman Nasional Gunung Ciremai .. .}

doi:10.1080/01436590020022547.

Grootaert, C., Narayan, D., Jones, V. N., \& Woolcock, M. (2004). Measuring social capital. Washington, D.C: The World Bank. doi:10.1596/0-8213-5661-5.

Groothuis, P. ., \& Miller, G. . (1997). The role of social distrust in risk-benefit analysis: A study of the siting of a hazardous waste disposal facility. Journal of Risk and Uncertainty, 15(3), 241-257. doi:10.1023/A:1007757326382.

Hakim, F. N., \& Wibisono, G. (2017). Modal sosial petani tembakau untuk peningkatan kesejahteraan sosial. Jurnal PKS, 1644), 369-380.

Hamdan, H., Achmad, A., \& Mahbub, A. S. (2017). Persepsi masyarakat terhadap status kawasan suaka margasatwa Ko'mara Kabupaten Takalar. Jurnal Hutan Dan Masyarakat, 9(2), 105. doi:10.24259/jhm.v9i2.2974.

Innah, H. S., Suharjito, D., Dharmawan, A. H., \& Darusman, D. (2013). Collective action typologies and reforestation in indigenous community of Biak-Papua, $X I X($ April), 11-22. doi:10.7226/jtfm.19.1.11.

Jones, N, Clark, J. R. A., Panteli, M., Proikaki, M., \& Dimitrakopoulos, P. G. (2012). Local social capital and the acceptance of Protected Area policies: An empirical study of two Ramsar river delta ecosystems in northern Greece. Journal of Environmental Management, 96(1), 55-63. doi:10.1016/j.jenvman.2011.10.012.

Jones, Nikoleta, Malesios, C., \& Botetzagias, I. (2009). The influence of social capital on willingness to pay for the environment among European citizens. European Societies, 11(4), 511-530. doi:10.1080/14616690802624168.

Lestari, T., Agussabti, \& Alibasyah, M. R. (2014). Partisipasi masyarakat adat dalam konservasi sumberdaya hutan di Kecamatan Kota Jantho Kabupaten Aceh Besar. Jurnal Manajemen Sumberdaya Lahan, 3(2), 506-516.

Marliani, R. (2010). Pengukuran dalam penelitian psikologi. Psympathic, Jurnal Ilmiah Psikolgi, III(1), 107-120.

Massiri, S. D., Nugroho, B., Kartodihardjo, H., \& Soekmadi, R. (2016). Preferensi dan motivasi masyarakat lokal dalam pemanfaatan sumberdaya hutan di taman nasional Lore Lindu, Provinsi Sulawesi Tengah. Jurnal Manusia dan Lingkungan, 23(2), 215. doi:10.22146/jml.18793.

Much, I., Subroto, I., Farisa, S., \& Haviana, C. (2016). Sistem informasi angket pengukuran skala kebutuhan materi pembelajaran tambahan sebagai pendukung pengambilan keputusan di Sekolah Menengah Atas menggunakan skala likert. Jurnal Transistor Elektro dan Informatika, 1(2), 1-12. doi:10.30659/ei.1.1.1-12.

Narsuka, Retnowati, D., \& Setiawan, B. (2009). Persepsi dan peranserta masyarakat lokal dalam pengelolaan Taman Nasional Gunung Merapi: Kasus Desa Umbulharjo, Kecamatan Cangkringan, Kabupaten Sleman. Universitas Gajah Mada.

Negara, P. D. (2011). Rekontruksi kebijakan pengelolaan kawasan konservasi berbasis kearifan lokal sebagai kontribusi menuju pengelolaan sumberdaya alam yang Indonesia. Jurnal Konstitusi, 4(2), 91-138.

Nordiansyah, H., Ismail, \& Bakrie, I. (2016). Penilaian efektivitas pengelolaan kawasan konservasi di kawasan cagar alam Padang Luway Kabupaten Kutai Barat. Jurnal Agrifor, 16. doi:10.31293/af.v15i1.1780.

Nugrahani, T. S., Suharni, S., \& Saptatiningsih, R. I. (2019). Potential of social capital and community participation in village development. Jejak, 12(1), 68-85. doi:10.15294/jejak.v12i1.15775.

Oja, H., \& Serano, V. (2016). Analisis pengembangan modal sosial masyarakat dalam mewujudkan pembangunan berkelanjutan di Kampung Tambat Distrik Tanah Miring Kabupaten Merauke. Societas: Jurnal Ilmu Administrasi dan Sosial, 5(02), 73-87. doi:10.35724/sjias.v5i02.560.

Oktadiyani, P., Muntasib, E. K. S. H., \& Sunkar, A. (2013). Modal sosial masyarakat di kawasan penyangga Taman Nasional Kutai (TNK) dalam pengembangan ekowisata. Media Konservasi, 18(1), 1-9. doi:10.29243/medkon.18.1.

Ostrom, E. (1990). Governing the commons: The evolution of institutions for collective action. Cambridge: Cambridge University Press. Retrieved from wtf.tw/ref/ostrom_1990.pdf.

Petts, J. (1998). Trust and waste management information expectation versus observation. Journal of Risk Research, 1(4), 307-320. doi:10.1080/136698798377079.

Pranadji, T. (2016). Penguatan modal sosial untuk pemberdayaan masyarakat pedesaan dalam pengelolaan agroekosistem lahan kering studi kasus di desa-desa (Hulu DAS) ex proyek bangun desa, Kabupaten 
Gunungkidul dan ex proyek pertanian lahan kering, Kabupaten Boyolali. Jurnal Agro Ekonomi, 24(2), 178. doi:10.21082/jae.v24n2.2006.178-206.

Prayogi, R., \& Danial, E. (2016). Pergeseran nilai-nilai budaya pada suku bonai sebagai civic culture di Kecamatan Bonai Darussalam Kabupaten Rokan Hulu Provinsi Riau. Humanika, 23(1), 61. doi:10.14710/humanika.23.1.61-79.

Qurniati, R., Febryano, I. G., \& Zulfiani, D. (2017). How trust influence social capital to support collective action in agroforestry development? Biodiversitas, 18(3), 1201-1206. doi:10.13057/biodiv/d1844.

Ristianasari, R., Muljono, P., \& S. Gani, D. (2016). Dampak program pemberdayaan model desa konservasi terhadap kemandirian masyarakat: Kasus di Taman Nasional Bukit Barisan Selatan Lampung. Jurnal Penelitian Sosial dan Ekonomi Kehutanan, 19(3), 173-185. doi:10.20886/jsek.2013.10.3.173-185.

Roslinda, E. (2018). Social capital of the community in the management of Danau Sentarum National Park, West Kalimantan, Indonesia. Biodiversitas, 194), 1249-1257. https://doi.org/10.13057/biodiv/d190410

Roslinda, E., Ekyastuti, W., \& Kartikawati, S. M. (2017). Social capital of community forest management on Nusapati Village, Mempawah District, West Kalimantan, Indonesia. Biodiversitas, 18(2), 548-554. doi:10.13057/biodiv/d180215.

Roslinda, E. M. I. (2018). Social capital of the community in the management of Danau Sentarum National Park , West Kalimantan , Indonesia, 194), 1249-1257. doi:10.13057/biodiv/d190410.

Sabir, L. O., Avenzora, R., \& Winarno, G. D. (2018). Stakeholders perception for ecotourism development in Tesso Nilo National Park. Media Konservasi, 23(1), 1-8. doi:10.29243/medkon.23.1.1-8.

Sadono, Y. (2013). Peran serta masyarakat dalam pengelolaan Taman Nasional Gunung Merbabu di Desa Jeruk Kecamatan Selo, Kabupaten Boyolali. Jurnal Pembangunan Wilayah \& Kota, 9(1), 53. doi:10.14710/pwk.v9i1.6526.

Saefulrahman, I. (2015). Kepemimpinan, modal sosial, dan pembangunan desa. Jurnal Ilmu Pemerintahan, 1(1), 149-166. doi:10.24198/cosmogov.v1i1.11804.

Sukoco, B. M., \& Hardi, H. (2013). Pengaruh modal sosial pada perilaku berbagi pengetahuan dan kinerja: Studi kasus di pemasok komponen otomotif Astra group. Jurnal Manajemen Teknologi, 12(3). doi:10.12695/jmt.2013.12.3.2.

Sulistyorini, I. S., Poedjirahajoe, E., Rahayu, L., \& Faida, W. (2018). Social capital in mangrove utilization for silvofishery : Case study in Kutai National Park, Indonesia, 24(August), 60-69. doi:10.7226/jtfm.24.2.60.

Supranto, J. (2000). Statistik: Teori dan aplikasi jilid 2 (6th ed.). Jakarta: PT Erlangga.

Szulecka, J., \& Secco, L. (2014). Local institutions, social capital and their role in forest plantation governance: lessons from two case studies of smallholder plantations in Paraguay. International Forestry Review, 16(2), 180-190. doi:10.1505/146554814811724810.

Uphoff, N. (2000). Understanding social capital: learning from the analysis and experience of participation. In P. Dasgupta \& I. Serageldin (Eds.), Social Capital: A Multifaceted Perspective. Washington D.C: World Bank.

Wartiharjono, S. (2017). Potensi konflik dan pembentukan modal sosial : belajar dari sebuah desa transmigran di Kalimantan Timur. Conflict potential and social capital construction : a case study of a transmigrant village in East Kalimantan. Masyarakat, Kebudayaan dan Politik, 30, 84-93. doi:10.20473/mkp.V30I12017.84-93.

Wijayanto, S. H. (2008). Structural equation modeling dengan lisrel 8. 8. Konsep \& Tutorial. Yogyakarta: Graha Ilmu.

Wiratno. (2018). Sepuluh cara baru kelola kawasan konservasi di Indonesia: Membangun "Organisasi Pembelajar.” (S. Bisro, Ed.). Jakarta: Direktorat Jenderal KSDAE Kementerian Lingkungan Hidup dan Kehutanan.

Yanto, E. W. B. (2012). Partisipasi masyarakat dalam usaha konservasi hutan. Journal of Educational Social Studies, 1(1), 8-12. 